\title{
ANALYSIS OF ENVIRONMENTAL AND GENETIC FACTORS IN GROWTH CHARACTERISTICS OF BALKAN GOAT
}

\author{
V. Caro Petrović ${ }^{1 *}$, Z. Ilić ${ }^{2}$ D. Ružić Muslić ${ }^{1}$, M. P. Petrović ${ }^{1}$, M. M. \\ Petrović $^{1}$, Z. Tomić ${ }^{1}$, G. Marinkov ${ }^{1}$ \\ ${ }^{1}$ Institute for Animal Husbandry, P.O.Box. 23, 11081 Zemun, Belgrade, Serbia \\ ${ }^{2}$ University of Pristina, Faculty of Agriculture, Kopaonicka bb, 38219 Lesak, Serbia \\ *Corresponding author: V. Caro Petrovic, e - mail: violycaro@yahoo.com
}

\begin{abstract}
Research was conducted on animals of Balkan goat breed. The impact of environmental factors on the weight of kids was analyzed, and also the value of genetic parameters of growth traits of kids to weaning had been examined. The body weight of kids varied depending on the year from $2.27 \pm 0.09 \mathrm{~kg}$ to $2.43 \pm 0.08 \mathrm{~kg}$ at birth and $10.81 \pm 0.58 \mathrm{~kg}$ to $11.13 \pm 0.51 \mathrm{~kg}$ at weaning. Variations depending on the season, ranged from $2.24 \pm 0.09 \mathrm{~kg}$ to $2.51 \pm 0.05 \mathrm{~kg}$. Sex also had an impact because the male kids had higher weight of $0.12 \mathrm{~kg}$ at birth and $0.20 \mathrm{~kg}$ at weaning. All differences caused by environmental factors were statistically significant $(\mathrm{P}<0.01)$. Single born kids in comparison with twin born kids had higher birth weight by $0.22 \mathrm{~kg}$ at birth and $0.37 \mathrm{~kg}$ in weaning. The differences were statistically significant $(\mathrm{P}<0.01)$. It is a known fact that the increase in litter size influences decrease in body weight of kids. We also found that the weight at birth is associated with body weight at weaning. Heritability for growth traits observed moving in the range of low values from $0.102 \pm 0.039$ to $0.153 \pm 0.041$. Repeatability of the observed traits varied from low to medium values in the interval from $0.118 \pm 0.030$ to $0.528 \pm 0025$.
\end{abstract}

factors

Key words: Balkan goat, growth characteristics, environment, genetic

\section{Introduction}

Goats are one of the most abundant species of domestic animals in the world and are grown in different geographical and climatic conditions. Due to different environmental factors, there are different breeds of goats with regard to milk yield, growth characteristics and prolificacy (Safari et al., 2005, Bosso et al., 2007, Kumar et al., 2007, Žujović et al., 2006, 2007, Concepta et al, 2008). In the Balkan Peninsula, goats are raised in various systems of production, ranging from the extensive to the intensive systems. In addition to known Saanen and Alpine 
goats, farmers in Serbia are raising local goats such as the Balkan breed, which is the most frequent in the mountainous regions of the country.

Despite the tradition, goat breeding in Serbia after the Second World War was completely ignored and the production of meat and milk was reduced to a minimum. In recent years, the government and science are increasingly devoting their attention improving the goat production because they found out that the farmers through meat and milk production can use natural resources and generate high profits. Population of Balkan goats has good genetic potential, but to make it realized it is necessary the systematic and programmed breeding. In this regard selection as a continuous process is the most reliable way to achieve genetic progress of the population. Breeding programs of goats are based on a number of genetic and environmental factors (Manfredi, et al., 2001, Rupp et al., 2004, Petrović et al, 2005, Bharathidhasan et al., 2009). Namely, it is known that the efficient work on the genetic improvement in goat breeding depends on the hereditary factors and environment, but also from optimal models for assessing the quality of animal (Lanari et al., 2003, Barillet et al, 2004). Any effective selection is largely dependent on heritability of the trait and its genetic relationship with other traits of economic importance (Portolana et al, 2002, Al-Shorepy et al., 2002, Kosum et al., 2004, Alade et al., 2010). Objective of this study is to examine the influence of some phenotypic and genetic parameters of growth traits in the Balkan goat.

\section{Material and methods}

The research was performed in the region of Stara Planina Mountain on the population of the Balkan goat. All tested animals had the same conditions of housing care and nutrition. Goats during the summer were on pasture and during the winter months in the building of a farm where they were fed hay and concentrate. Statistical analysis was performed by GLM procedure of SAS statistical package program (SAS, 2005) using the next model:

Yijklmn $=\mu+\mathrm{Ji}+\mathrm{Sj}+\mathrm{Ak}+\mathrm{Tl}+\mathrm{Dm}+$ eijklmn,

where:

Yijklmn $=$ body weight of nth kid of $m$ age of dam, $l$ birth type, $k$ sex and born during $j$ season in $i$ year

$\mu=$ overall population mean

$\mathrm{Ji}=$ effect of $i$ year

$\mathrm{Sj}=\operatorname{effect}$ of $j$ season

$\mathrm{Ak}=$ effect of $k$ sex of kid

$\mathrm{Tl}=$ effect of $l$ type of birth 
$\mathrm{Dm}=$ effect of age of doe

eijklmn $=$ residual error

The fixed effects included in the model were year and season of birth, sex of kid, type of birth and age of dam. Heritability and repeatability estimates were computed by the method of paternal half-sib analysis using VARCOMP procedures of SAS (2005).

\section{Results and Discussion}

Estimates of Least squares means of birth and weaning weight of kids are shown in table 1.In Table 1 we can see that phenotypic parameters expressed through the body weight of kids varied depending on the year from $2.27 \pm 0.09 \mathrm{~kg}$ to $2.43 \pm 0.08 \mathrm{~kg}$ at birth and $10.81 \pm 0.58 \mathrm{~kg}$ to $11.13 \pm 0.51 \mathrm{~kg}$ at weaning. The variation in birth weight of kids born in different years reflected variation in level of management. Our findings indicate that variations depending on the season, ranged from $2.24 \pm 0.09 \mathrm{~kg}$ to $2.51 \pm 0.05 \mathrm{~kg}$. Sex also had an impact because the male kids had a higher weight of $0.12 \mathrm{~kg}$ at birth and $0.20 \mathrm{~kg}$ at weaning. Any differences caused by environmental factors were statistically significant $(\mathrm{P}<0.01)$.

Effect of type of birth and age of dam on birth and weaning weight of kids is shown in Table 2. Single kids are heavier by $0.22 \mathrm{~kg}$ than twins at birth and 0.37 $\mathrm{kg}$ in weaning. The differences were statistically significant $(\mathrm{P}<0.01)$. We also found that the weight at birth is associated with body weight at weaning. Age of doe significantly affected birth weight. Difference between ages 2 and 3 was significant $(\mathrm{P}<0.05)$ but between ages 2 and other ages $(4,5,6)$ it was very significant $(\mathrm{P}<0.01)$. Results of the heritability and repeatability are shown in Table 3 .

Table 1. Effect of year, season and sex on birth and weaning weight of kids

\begin{tabular}{|l|c|c|c|c|c|c|}
\hline \multirow{2}{*}{$\begin{array}{c}\text { Year of } \\
\text { birth }\end{array}$} & \multicolumn{3}{|c|}{ Birth weight (kg) } & \multicolumn{3}{c|}{ Weaning weight (kg) } \\
\cline { 2 - 7 } & $\mathrm{N}$ & Mean & S.E. & $\mathrm{N}$ & Mean & S.E. \\
\hline Year & 125 & 2.27 & \pm 0.09 & 119 & 10.81 & \pm 0.58 \\
\hline 1 & 120 & 2.38 & \pm 0.06 & 116 & 10.85 & \pm 0.39 \\
\hline 2 & 118 & 2.43 & \pm 0.08 & 112 & 11.13 & \pm 0.51 \\
\hline 3 & 128 & 2.51 & \pm 0.05 & 123 & 11.18 & \pm 0.50 \\
\hline Season & \pm 0.08 & 119 & 10.90 & \pm 0.39 \\
\hline Summer & 125 & 2.33 & \pm 0.09 & 117 & 10.71 & \pm 0.32 \\
\hline Autumn & 123 & 2.24 & \pm 0.05 & 117 & 11.03 & \pm 0.31 \\
\hline Winter & \multicolumn{7}{|l|}{} \\
\hline Sex & 124 & 2.42 & \pm 0.07 & 116 & 10.83 & \pm 0.41 \\
\hline Male & 121 & 2.30 & &
\end{tabular}


Heritability for growth traits observed moving in the range of low values from $0.102 \pm 0.039$ to $0.153 \pm 0.041$. Repeatability of the observed traits varied from low to medium values in the interval from $0.118 \pm 0.030$ to $0.528 \pm 0025$.

Table 2. Effect of type of birth and age of doe on birth and weaning weight of kids

\begin{tabular}{|c|c|c|c|c|c|c|}
\hline \multirow{2}{*}{ Effect } & \multicolumn{3}{|c|}{ Birth weight $(\mathrm{kg})$} & \multicolumn{3}{c|}{ Weaning weight $(\mathrm{kg})$} \\
\cline { 2 - 7 } & $\mathrm{N}$ & Mean & S.E. & $\mathrm{N}$ & Mean & S.E. \\
\hline \multicolumn{7}{|l|}{ Type of birth } \\
\hline Single & 125 & 2.47 & \pm 0.05 & 119 & 11.12 & \pm 0.57 \\
\hline Twins & 120 & 2.25 & \pm 0.08 & 116 & 10.75 & \pm 0.36 \\
\hline \multicolumn{7}{|l|}{ Age of doe } \\
\hline 2 & 128 & 2.20 & \pm 0.06 & 123 & 10.70 & \pm 0.48 \\
\hline 3 & 125 & 2.29 & \pm 0.09 & 119 & 10.87 & \pm 0.38 \\
\hline 4 & 123 & 2.36 & \pm 0.08 & 117 & 10.93 & \pm 0.34 \\
\hline 5 & 124 & 2.58 & \pm 0.04 & 117 & 11.06 & \pm 0.30 \\
\hline 6 & 121 & 2.37 & \pm 0.06 & 116 & 11.09 & \pm 0.43 \\
\hline
\end{tabular}

Variations in phenotypic parameters similar to our results are stated by other authors (Bagnicka and Lukasyewicz, 1999, Žujović et al., 2007, Memiši et al., 2009). Some authors, such as Horst et al. (1993), Das et al. (1996) and Hermiz (2001) informed that the season has a significant effect on body weight of kids, which is consistent with our research. Influence of season in our study can be interpreted as a factor in nutrition. Specifically, during the summer the food more accessible, so kids have a higher body weight. During autumn and winter, the level of nutrition decreased as well as kids' body weight. Said et al. (1990) and Das et al. (1996) stated that some environmental effects and availability of feed quantity may affect the weight of kids.

The influence of sex of kids can be attributed to different hormonal status between male and female kids. According to Hossein et al. (2011) single born kids in comparison with twin born kids had higher birth weight and weaning weight. It is a known fact that the increase in litter size, reduced body weight of kids. In our research, birth is associated with body weight at weaning. With this statement agreed many other authors, including Horst et al. (1993), Gebrelul et al. (1994) and Das et al. (1996). Age of doe significantly affect birth weight and our results is partially agrees with other results that were reported earlier (Das et al., 1996 and Hermiz, 2001 and 2005). Van der Westhuizen et al. (2004) stated that kids born to young does (2-year-old does) had lower body weights up to 16 months of age than kids born to 4- to 8-year-old does. Birth, weaning and 8-month body weights of kids born to older does were also lower. Authors concluded that age of dam is one of the internal factors that have a marked influence on overall efficiency of the flock. 
Table 3. Heritability and repeatability estimates of live weight and growth traits of kids

\begin{tabular}{|l|c|c|}
\hline \multicolumn{1}{|c|}{ Trait } & Heritability & Repeatability \\
\hline Body weight at birth & $0.153 \pm 0.041$ & $0.196 \pm 0.022$ \\
\hline Body weight at 3 month & $0.110 \pm 0.044$ & $0.211 \pm 0.041$ \\
\hline Weight at 6 month & $0.121 \pm 0.057$ & $0.528 \pm 0.025$ \\
\hline Weight at 12 month & $0.138 \pm 0.045$ & $0.118 \pm 0.030$ \\
\hline Weight at 18 month & $0.121 \pm 0.037$ & $0.171 \pm 0.052$ \\
\hline DG ${ }^{1}$ up to 3 month & $0.102 \pm 0.039$ & $0.188 \pm 0.011$ \\
\hline DG up to 6 month & $0.123 \pm 0.050$ & $0.231 \pm 0.039$ \\
\hline DG up to 12 month & $0.118 \pm 0.047$ & $0.123 \pm 0.041$ \\
\hline DG up to 18 month & $0.121 \pm 0.051$ & $0.163 \pm 0.055$ \\
\hline
\end{tabular}

Heritability for body weight at birth in our research (0.153) is lower than what we found in the literature (Al-Shorepy, et al., 2002; Portolana et al., 2002 and Kosum,et al., 2004). Higher values of heritability were found Boso et al. (2007) who reported that heritability for BW, W120, W360, GR0-4 and GR4-12 were $0.5,0.43,0.30,0.32$ and 0.11 for goats and $0.39,0.54,0.21,0.54$ and 0.23 for sheep, respectively. Hermiz et al. (2008) report that heritabilities for BWT, WWT, WT6M, WT9M and WT12M were $0.30,0.38,0.17,0.19$ and 0.28 , respectively. Repeatabilities of growth traits are in agreement with Alade et al. (2010), but most of the estimates are higher than values in the literature (Odubote and Akinokun, 1992 and Das et al., 1996).

\section{Conclusion}

These results showed that there is a strong influence of environmental factors on the body weight of kids at birth and weaning. Also can be noted that heritability for body weight and average daily gain of kids is low and variable. Repeatability of the observed traits varied from low to medium values. We can say that despite the Balkan goat adapted to the conditions in region of Stara Planina Mountain there is a high variability of the observed parameters. This means that in the previous period, adequate selection is not carried out. For the consolidation of production traits is necessary to develop a serious breeding program in the future, especially since the Balkan goat is an important genetic resource.

\section{Acknowledgements}

This study is part of the projects TR 31001 "An environmental approach and implementation of modern biotechnologies as a basis for the improvement of ruminant breeding technology", and TR 31053 "Modern biotechnology solutions in 
the breeding and feeding of cattle sheep and goats for the production of valuable and safety food" financially supported by the Ministry of Education and Science of the Republic of Serbia.

\section{Analiza spoljnih i genetskih faktora u osobinama porasta balkanske koze}

V.Caro Petrović, Z. Ilić, D. Ružić Muslić, M. P. Petrović, M. M. Petrović, Z. Tomić, G.Marinkov

\section{Rezime}

Istraživanje je sprovedeno kod balkanske rase koza. Izvršena je analiza uticaja spoljnih faktora na težinu jaradi , a takođe je ispitivana vrednost genetskih parametara osobina porasta do odbijanja.Telesna masa jaradi u zavisnosti od zavisi od godine varira od $2,27 \pm 0,09 \mathrm{~kg}$ do $2.43 \pm 0.08 \mathrm{~kg}$ na rođenju i $10.81 \pm 0.58 \mathrm{~kg}$ do $11.13 \pm 0.51 \mathrm{~kg}$ pri odlucivanju. Varijacije u zavisnosti od sezone, kreću se u rasponu od $2.24 \pm 0.09 \mathrm{~kg}$ do $2,51 \pm 0.05 \mathrm{~kg}$. Pol je takođe imao uticaj, jer su muška jarad imala veću težinu za $0,12 \mathrm{~kg}$ na rođenju i $0.20 \mathrm{~kg}$ pri odlucivanju. Sve razlike izazvane faktorima okoline bile su statistički značajne $(P<0,01)$. Jarad rođena kao jedinci u poređenju sa blizancima imaju više porođajne težine za 0,22 $\mathrm{kg}$ na rođenju. Takođe su u prednosti i za $0.37 \mathrm{~kg}$ pri odbijanju. Razlike je statistički značajna $(\mathrm{P}<0,01)$. To je poznata činjenica da povećanje veličine legla, smanjuje telesnu masu jaradi. Takođe smo ustanovili da masa na rođenju je povezana sa telesnom masom pri odlučivanju. Heritabilnost za osobine porasta se kreće u rasponu od $0,102 \pm 0,039$ do $0,153 \pm 0,041$. Ponovljivost posmatranih osobina varira od niskih do srednjih vrednosti u intervalu od 0.118 do $0.528 \pm$ $0.0300025 \pm$.

\section{References}

ALADE N. K., DILALA M. A., ABDULYEKEEN A. O. (2010): Phenotypic and genetic parameter estimates of litter size and body weights in goats, I.J.S.N.1: 262266.

AL-SHOREPY S. A., ALHADRAMI G. A., ABDULWAHAB K. (2002): Genetic and phenotypic parameters for early growth traits in Emirati goats. Small Ruminant Research, 45:217-223.

BAGNICKA E., LUKASZEWICZ M. (1999): Genetic and environmental variation of dairy traits in Polish population of goats. Animal Science Papers and Reports, 17: 59-65. 
BARILLET F., ASTRUC J. M., CLEMENT V., LAGRIFOUL G., MARIE C., PIACERE A., RUPP R., MANFREDI E. (2004). Improving milk yield and quality in dairy sheep and goats trough genetics. International symposium, Book of papers, 1-5, Spain, 28-30 October.

BHARATHIDHASAN A., RITA N., GOPU P., SUBRAMANIAN A., PRABAKARAN R., RAJENDRAN R. (2009): Effect of nongenetic factors on birth weight, weaning weight and preweaning gain of barbari goat. Tamilnadu J. Veterinary \& Animal Sciences, 5:99-103.

BOSSO N. A., CISSÉ M.F., VAN DER WAAIJ E.H., FALL A., VAN ARENDONK J.A.M. (2007): Genetic and phenotypic parameters of body weight in West African Dwarf goat and Djallonké sheep. Small Ruminant Research, 67:271-278.

CONCEPTA M., GUILHERMA S. F., HELDE L., LAILA T. D., RODRIGO D. T., LUCI S. M. (2008): Growth of Saanen, Alpine and Toggenburg goats in the Federal District, Brazil: Genetic and environmental factors. Ciencia Animal Brasileira, 9: 68-75.

DAS S. M., REGE J. E. O., SHIBRE M. (1996): Phenotypic and genetic parameters of growth traits of Blended goats at Malya, Tanzania. Proceeding of the third Biennial Conference of the African Small Ruminant Research Network. ILRI. p: 63-70 ., Nairobi, Kenya.

GEBRELUL S., SARTIN L. S., IHEANACHO M.(1994) :Genetic and non-genetic effects on the growth and mortality of Alpine, Nubian and crossbred kids. Small Rumin. Res.,13: 169-176.

HERMIZ H. N., ALKASS J. E., HOBI A. A., ASOFI M. K. (2008). Genetic and phenotypic parameters of body weight in Irac local goat and their crosses with Damascus. Conference on Biological Sciences, University of Dohuk 6-8 May, 2008. J. Duhok Univ., 12:189-194.

HERMIZ H. N. (2001): Genetic evaluation of local goats and their crosses Using Some Productive Traits. Ph.D. Thesis, University of Baghdad, Iraq.

HERMIZ H. N.(2005):Genetic evaluation of Iraqi local goats and their crosses depending on their growth rates. Iraqi J. Agric. Sci., 36:181-189.

HORST P.,ZARATE A. V., GUNES H., YALCIN C. (1993):Growth rate and wool production of crossbred progeny from Turkish and North American Angora goats.Animal Research and Development, 38: 92-99.

HOSSEIN B., MAHMOUD G. (2011): Effects of Environmental Factors on Body Weight of Sistani Goat at Different Ages. Journal of Animal and Veterinary Advances, 10:2819-2823.

KOSUM N., TASKIN T., AKBAS Y., KAYMAKEI M. (2004): Heritability estimates of birth and weaning weight in Saanen, Bornova and Saanen $\mathrm{x}$ Kilis goats. Pakistan Journal of Biological Sciences, 7: 1963-1966.

KUMAR A., SINGH U., TOMAR A. K. S. (2007): Early growth parameters of Kutchi goats under organized farm. Indian Vet. J., 83 :105-106. 
LANARI M. R., TADDEO H., DOMINGO E., CENTENO M. P., GALlO L. (2003):Phenotypic differentiation of exterior traits in local Criollo goat population in Patagonia Argentina). Arch. Anim. Breed, 46: 347-356.

MANFREDI E., PIACERE A., LAHAY P., DUCROCQ V. (2001): Genetic parameters of type appraisal in Saanen and Alpine goats . Livestock Production Science, 70: 183-189.

MEMISI N., ZUJOVIĆ M., TOMIC Z., PETROVIC P.M. (2009): The effect of time of weaning on body mass and gain of kids. Biotechnology in Animal Husbandry, 25:993-998.

ODUBOTE I. K., AKINOKUN J. O. (1992): Estimates of genetic parameters for economic traits in West African Dwarf Goat. Nigerian Journal of Animal

Production, 19:114- 119.

PETROVIC P.M, MEKIC C., RUZIC MUSLIC D., ZUJOVIC M. (2005):Genetic principles relating to improvement of milk yield in sheep and goats. Biotechnology in Animal Husbandry, 21:73-78.

PORTOLANA B., TODORA M., FINOCCHIARO R., VANKAAM J. H. C. M. (2002): Estimation of the genetic and phenotypic variance of several growth traits of the Sicilian Girgentana goat. Small Ruminant Research, 45: 247-253.

RUPP R., CLEMENT V., PIACERE A., MANFREDI E. (2004): Goat milk somatic cell count is a heritable traits. 55-th Annual meeting of EAAP, 5-8. September, Slovenia, Book of Abstracts, N. GM2.

SAFARI J., MUSHI D. E., MTENGA L. A., EIK LO., KIFARO G. C., MUHIKAMBELE V. R. M., NDEMANISHO E. E. MAEDA MACHANG'U D., KASSUKU A. A., KINMBITA E. N., ULVUND M. (2005): A note on growth rates of local goats and their crosses with Norwegian goats at village level in Tanzania. Livestock Research for Rural Development. 17, Art. 47.

SAID S. I., BADAWI F. S., AL-RAWI A. A. (1990): Comparison of white and brown Angora goat with respect to liveweight. $4^{\text {th }}$ World Congress on Genetics Applied to Livestock Production. 23-27, July. Edinburgh, 15: 201-204.

SAS. (2005). User's Guide. Statistical Analysis System Institute, Inc., Cary, NC, USA.

VAN DER WESTHUIZEN J. M., WENTZEL D., GROBLER M. C. (2004): Angora goats and mohair in South Africa. Revised edition, Port Elizabeth, South Africa.

ŽUJOVIC M., PETROVIC P. M., TOMIC Z., RUZIC D., NESIC Z. ( 2007):Correlation of body mass of Serbian white goat and type of kidding and production traits. Biotechnology in Animal Husbandry,23:365-375.

ŽUJOVIĆ, M., TOMIĆ ZORICA, PETROVIĆ, P.M., MEKIĆ, C., SNEŽANA IVANOVIĆ, NEŠIĆ ZORICA (2006): Development and perspective of goat production in Serbia. Biotechnology in Animal Husbandry 22,43-56. 